\title{
VER, LER, TOCAR E PARTICIPAR DO ANÚNCIO IMPRESSO DA CERVEJA SOL
}

\author{
See, read, touch and interact with the sol beer press add
}

Visualizar, leer, jugar y participar del anúncio impreso de la cerveza Sol

Fernanda Rodrigues Pucci ${ }^{1}$

\section{Resumo}

Este artigo é uma pequena parte de um trabalho maior e apresenta uma análise teórica, e de certo modo técnica, de um dos anúncios de lançamento da cerveja SOL no Brasil. Resgata alguns conceitos de análise da imagem (icônica) e retórica publicitárias com foco no anúncio impresso que possui elementos interativos (exige manipulação). O objetivo principal é conhecer como ocorre a formação de sentido nas mensagens publicitárias que usam da interação com o receptor. O estudo é embasado por Peirce, Eco e Barthes.

Palavras-chave: publicidade; semiótica; imagem; interação.

\begin{abstract}
This article is a small part of a larger work and presents a theoretical and technical analysis from one of the ads for the launch of SOL beer in Brazil. For that draws some theoretical concepts of image analysis and advertising rhetoric focused on a interactive press add (requires manipulation). The main objective is to know how does the formation of meaning in advertising messages that use the interaction with the receptor occurs. The study is based on theories by Peirce, Barthes and Eco.
\end{abstract}

Keywords: advertising, semiotics; image; interaction.

\section{Resumen}

Este artículo es una pequeña parte de una obra más grande y presenta un análisis teórico, y técnico de uno de los anuncios para el lanzamiento de la cerveza SOL en Brasil. Señala algunos conceptos de análisis de imagen y la retórica de publicidad enfocada en un anuncio impreso que cuenta con elementos interactivos (requiere la manipulación). El objetivo

\footnotetext{
${ }^{1}$ Mestranda do PPGCOM/UTP, coordenadora e professora do curso de Tecnologia em Marketing INESUL/FIPAR, e professora de Publicidade e Propaganda FAPAR E-mail: ferpucci@ hotmail.com.
} 
Ver, Ler, Tocar E Participar Do Anúncio Impresso Da Cerveja Sol.

de Fernanda Rodrigues Pucci

principal es conocer cómo se dá la formación de significado en los mensajes publicitarios que utilizan la interacción. El estudio se basa por Peirce, Barthes y Eco.

Palabras-clave: publicidad, semiótica, imagen, interacción.

\section{INTRODUÇÃO}

As imagens fazem cada vez mais parte da comunicação contemporânea com diferentes características, pois nossa cultura tem um substrato predominantemente visual. Se analisarmos criticamente, essa "civilização de imagem" pode ser entendida como uma “civilização do clichê", ou então do estereótipo, por estar focada na persuasão, seja ela implícita ou explícita. Toda imagem parece trazer em si o desejo de convencer, o que significa que a exploração da dimensão visual (icônica) é resultado de uma estratégia significativa e, como tal, persuasiva. Cada imagem esforça-se em convencer à sua maneira, seja representando coisas que existem no mundo ou outras que nunca existiram, podendo ser publicitária, institucional, educativa, etc. Por outro lado, qualquer representação da realidade sofre sempre a interferência da técnica utilizada por quem a cria e o ponto de vista do observador. Para analisar anúncios publicitários semioticamente é importante que sejam levadas em consideração algumas outras abordagens sobre essas mensagens, para que possam dialogar entre si, e posteriormente serem aplicadas ao objeto de estudo. Segundo Lúcia Santaella,

[...] para uma análise afinada, a aplicação semiótica reclama pelo diálogo com teorias mais específicas dos processos de signos que estão sendo examinados. Assim, por exemplo, para se analisar semioticamente filmes, essa análise precisa entrar em diálogo com teorias específicas de cinema. [...] Não se pode fazer análise de peças publicitárias sem algum conhecimento de sintaxe visual, design, etc.. (2002: 06)

Dessa maneira, este artigo toma como objeto de estudo um tipo específico de publicidade impressa que possui elementos interativos, ou seja, o que se pretende analisar é uma peça publicitária que utiliza a forma e o suporte como parte integrante da mensagem, principalmente pelo fato de exigir uma certa manipulação para que se possa compreender a mensagem por inteiro. Trata-se de uma propaganda de cerveja veiculada na mídia impressa: uma das peças da campanha publicitária de lançamento da nova cerveja SOL, no Brasil.

Partindo da ideia de que a análise semiótica permite a compreensão das múltiplas dimensões e manifestações das diferentes linguagens que se apresentam em diferentes 
Ver, Ler, Tocar E Participar Do Anúncio Impresso Da Cerveja Sol.

de Fernanda Rodrigues Pucci

esquemas perceptivos, como palavras, imagens, formas, cores ou texturas, sons e silêncios, cada um deles envolvendo variados efeitos, que vão do puramente emocional até elaborações metafóricas e simbólicas, a abordagem da peça publicitária da cerveja SOL levará em conta que todos esses efeitos podem ser intencionalmente aproveitados para a persuasão, considerando-se o repertório do público-alvo.

Para isso serão tomadas como base as teorias dos signos (Charles Sanders Peirce, Umberto Eco e Roland Barthes), os estudos das imagens (Martine Joly e outros) assim como a semiótica aplicada, por meio dos textos de Lúcia Santaella e Denise Guimarães, entre outros. A questão da interatividade será embasada por textos de Arlindo Machado e Alex Primo.

\title{
2. CONSIDERAÇÕES TEÓRICAS
}

Para uma análise semiótica, devem ser considerados os três tipos de efeitos de uma mensagem: efeitos interpretativos emocionais, efeitos reativos - ou seja, aqueles que levam a uma ação - e, ainda, efeitos lógicos, que têm a natureza do pensamento racional. A pluralidade da própria base intersemiótica de uma mensagem publicitária prevê a operação integradora dos diversos signos e, portanto, exige uma recondução à unidade, que é função do Interpretante peirceano. Para Peirce,

\begin{abstract}
A referência a um interpretante é tornada possível e justificada por aquilo que torna possível e justifica a comparação, e isto é claramente a diversidade de impressões. (...), mas como existe uma pluralidade de impressões temos um sentimento de complicação ou confusão, que nos conduz a diferenciar esta impressão daquela, e então, tendo sido diferenciadas, elas exigem ser conduzidas à unidade. Agora elas não são conduzidas à unidade até que as concebamos conjuntamente como sendo nossas, isto é, até que as refiramos a um conceito que seja seu interpretante. Assim, a referência a um interpretante surge a partir da junção de diversas impressões, e conseqüentemente não reúne um conceito à substância, como as outras duas referências fazem, mas une diretamente a pluralidade da própria substância. (2001:288-289)
\end{abstract}

Portanto, verifica-se que, no processo interpretante, as diferentes impressões decorrentes da percepção dos fenômenos ou objetos podem ser unidas por um conceito: o interpretante do signo.

Roland Barthes, em Elementos de Semiologia, define que "o signo é composto de um significante e um significado. O plano dos significantes constitui o plano de expressão e o dos significados o plano de conteúdo." (1985: 43). Na publicidade, podem ser utilizados tanto os signos que têm uma analogia direta com o objeto representado, como 
Ver, Ler, Tocar E Participar Do Anúncio Impresso Da Cerveja Sol.

de Fernanda Rodrigues Pucci

aqueles que têm sentidos simbólicos, culturais e determinados pela convenção. O símbolo pode ser metáfora e metonímia ao mesmo tempo. E na comunicação (propaganda/publicidade) o processo da construção da mensagem utiliza da figuração de sentido, o que explica a presença de símbolos.

É preciso um empenho publicitário sistemático para criar um vínculo semiótico entre uma imagem e determinado produto. $\mathrm{O}$ caráter da representatividade simbólica não é uma mera convenção. A simbolização tem força quando se utiliza de algo que existe na mente para ajudar a fortalecer a ideia ou o conceito simbolizado. Em alguns casos, o nome do produto vem escrito em tipos e cores especiais que têm a função de simbolizar o produto. O exemplo mais famoso é o da Coca-Cola, em que a cor vermelha foi escolhida com o fim de criar uma relação com o objeto já definida no inconsciente coletivo, o que caracteriza uma predisposição. Tais estratégias são muito exploradas nas marcas, rótulos, embalagens e propagandas de cervejas, por exemplo.

Há imagens que têm um significado óbvio e único, não oferecendo outras possibilidades de leitura além do que aparece representado. A publicidade se vale desse tipo de imagens para reduzir o nível de ambiguidade da mensagem, quando o objetivo é apresentar, ou até mesmo impor, um determinado produto no mercado.

A ambiguidade pode ser, por outro lado, intencional, quando a proposta é uma apresentação mais estética e original do produto. Nesse caso, diversas conotações são possíveis, permitindo leituras múltiplas. Tudo depende do produto e do repertório específico de seu público-alvo.

No caso da propaganda da cerveja SOL, analisada a seguir, percebe-se que a ambiguidade foi evitada, pois o grau de figuração, os apelos formais e cromáticos são bastante óbvios. Podemos identificar, no anúncio, alguns estereótipos das propagandas deste tipo de produto, entretanto, percebe-se a utilização de elementos redundantes no contexto das propagandas de cervejas, somados a elementos originais que constituem o apelo à manipulação do material impresso pelo leitor/receptor. Este é o diferencial da peça aqui estudada.

Dentre as atividades do sistema capitalista, a publicidade é a que mais se vale do princípio de incentivar, cada vez mais, o consumo. Além de ter um bom produto a oferecer, é preciso torná-lo conhecido e, também, fazer com que possíveis compradores passem a desejar sua aquisição. É neste ponto que entra a Retórica. Considerando que a publicidade tem por objetivo principal convencer o público a consumir e a Retórica é 
Ver, Ler, Tocar E Participar Do Anúncio Impresso Da Cerveja Sol.

de Fernanda Rodrigues Pucci

exatamente a arte da persuasão, não é difícil compreender porque o discurso publicitário recorre aos procedimentos retóricos para atingir seus objetivos.

Antigamente, a Retórica visava mais do que um assentimento racional, pretendia também promover uma concordância emocional. Umberto Eco afirma que, com o passar do tempo, a retórica deixou de ser vista como uma fraude sutil, como era considerada por muitos, para atingir a posição de

[...] técnica de um raciocinar humano controlado pela dúvida e submetido a todos os condicionamentos históricos, psicológicos, biológicos de qualquer ato humano. [...] a retórica procedia a um recenseamento desses modos de pensar, dessas opiniões comuns e adquiridas, e desses argumentos já assimilados pelo corpo social, correspondentes a sistemas de expectativas pré-constituídos. (Eco 1997:73-74)

Em outras palavras, para certificar-se de que seus argumentos seriam aceitos, o orador deveria utilizar um conjunto de ideias de consenso geral antes de introduzir um novo conceito. Ou seja, para ter a receptividade esperada, a mensagem deveria equilibrar informação nova com informação já conhecida. O autor explica que há diferentes graus retóricos e diferentes tipos de discurso, que vão desde o discurso filosófico até as técnicas da propaganda e da persuasão de massa.

O pensador italiano salienta ainda que, quando as figuras de retórica são usadas de modo criativo, elas não servem apenas para ornamentar um conteúdo, mas "contribuem para delinear um conteúdo diverso" (Eco 2000:236).

Em diversas obras e por décadas, Umberto Eco tem utilizado conceitos e caminhos distintos para se alcançar os sentidos conotados. De modo geral, os resultados finais são muito similares aos apontados por Barthes e Joly. A retórica da imagem indica sempre uma possibilidade de um sentido segundo, o que Barthes denomina de sentido conotado e Joly explica dizendo que "uma imagem pretende sempre dizer algo diferente do que representa no primeiro grau, isto é, no nível da denotação" (Joly 1996: 83).

Denise Guimarães refere-se a outros efeitos de sentido, que podem ser observados nas peças publicitárias, em termos de recursos retóricos - tais como ambiguidade, metáforas, metonímias, antíteses, hipérboles, paradoxos, etc. - que funcionam na publicidade da mesma forma que nas outras manifestações artísticas. "Neste caso, o jogo retórico pode traçar conexões imprevisíveis ou escassamente previstas e desfrutadas" (Guimarães 2007: 151). A autora entende que os recursos retóricos podem redimensionar o texto publicitário em suas qualidades artísticas, assim como ocorre num quadro, ou mesmo num poema, delineando novos significados nas imagens e entre as 
Ver, Ler, Tocar E Participar Do Anúncio Impresso Da Cerveja Sol.

de Fernanda Rodrigues Pucci

imagens. Essas novas percepções dependem de um conceito imediato ligado a outro mais mediato que permite as distinções: é a representação mediadora que Peirce denomina Interpretante.

Martine Joly comenta um anúncio publicitário de extrato de tomate, como exemplo para o entendimento retórico da conotação:

A fotografia (significante) que me permite reconhecer tomates,pimentões ou cebolas (significados) constitui um signo pleno (um significante ligado a um significado). Contudo, esse signo pleno prossegue sua dinâmica significativa tornando-se o significante de um significado segundo, 'frutas e legumes mediterrâneos, Itália. (Joly 1996:83).

Partindo do exemplo citado e levando para o caso da propaganda de cerveja aqui analisada, é possível perceber a necessidade do conhecimento dos códigos para haver uma leitura eficiente. Os códigos precisam ser conhecidos e de domínio social. Saber utilizar as conotações em termos retóricos significa estar atento aos contextos em que os signos se encontram, pois, qualquer leitura depende dos grupos sociais em que os destinatários estão inseridos; dos lugares que eles habitam e de seu repertório.

Os sentidos e as representações podem ser variados conforme as características particulares de cada grupo social, o que deve orientar as estratégias persuasivas de uma mensagem publicitária. É grande a diferença entre significante e significado em sociedades diferentes. Segundo Roland Barthes: "Cada sistema de significantes corresponde, no plano dos significados, a um corpo de práticas e técnicas; esses corpos de significação implicam, por parte dos consumidores de sistemas, diferentes saberes” (Barthes 1971: 49).

Enfim, o mais importante, no caso da publicidade, é estar atento às diversas possibilidades de leitura que são decorrentes do repertório do público-alvo escolhido, pois a chamada retórica conotativa dependente diretamente do contexto em que ela foi produzida e, em consequência, disso depende sua eficácia.

\section{INTERATIVIDADE: A MANIPULAÇÃO DO OBJETO}

A interatividade pode ser definida como o ato de interferir e provocar uma reação, ou desencadear um processo de reação em bidirecionalidade, em que "os pólos emissor e receptor são intercambiáveis e dialogam entre si durante a construção da mensagem" (Machado apud. Primo, Moura, Silveira, Santos 2004: 2). Essa reação ou intervenção qualificam o processo da interatividade. 
Ver, Ler, Tocar E Participar Do Anúncio Impresso Da Cerveja Sol.

de Fernanda Rodrigues Pucci

A manipulação de um objeto de forma a alterá-lo de seu estado de inércia e assim produzir algum sentido pode ser enquadrada nesse processo. E o objeto, neste caso, situase como instrumento mediador entre o homem e a mensagem. Santaella diz que, "A ação lógica do signo é funcionar como mediador entre o objeto e o efeito que produz numa mente atual ou potencial." (2000: 24). O que deve ser enfatizado aqui é que a publicidade impressa interativa, que hoje se apresenta como um recurso a ser usado em busca do despertar da atenção, fixa-se como bem mais do que isso. As campanhas que buscam o tipo de interação "física" (através da manipulação da peça), além de chamarem a atenção, conseguem alterar a maneira de percepção da mensagem em seu ponto de aproximação cognitiva com o receptor. Em tempos de internet (que, aliás, firma-se por possuir esta característica tão peculiar que é a interatividade), cada meio novo provoca certa transformação nos hábitos das pessoas, alterando a dinâmica de suas vidas e desenvolvendo um outro tom perceptivo.

$\mathrm{Na}$ evolução dos meios de comunicação, acentua-se com naturalidade a intervenção neles pelo homem: da fotografia ao cinema, da linearidade da televisão à pluralidade da internet - interativa por excelência, com suas escrituras hipertextuais. Cada meio novo provoca certa transformação nos hábitos das pessoas, alterando a dinâmica de suas vidas e desenvolvendo uma nova ordem perceptiva. A pluralidade da linguagem interativa e a pluralidade sígnica apresentam-se implícitas umas nas outras, uma vez que, assim como o signo está para a representação do real, o hipersigno está para o virtual. Quando se fala de signo atribui-se a ele o caráter de agente postulador do pensamento que opera no universo da cognição e está ligado ao seu objeto por uma conexão de fato, ou uma representação, indução ou simbolização. Da mesma forma, ao se falar de hipersigno (ligado ao conceito de hipermídia) compreende-se que cumpre seu papel de signo, ao apresentar-se primeiramente como simulação do signo real.

O signo integra e desencadeia estruturas de análise semelhantes e correspondentes, por isso, estabelecer um paralelo da análise do signo com os meios interativos é estabelecer uma relação entre sua ação interativa e suas relações semióticas. É preciso comparar o signo no sentido de como se relaciona com outros signos, despertando uma leitura bidirecional e interativa.

Assim como no signo, as qualidades do hipersigno revelam-se em função de sua aparência primeira, porém o hipersigno é objeto principal da mediação hipermidiática e soma características como mutação, dinamicidade, volatilidade, sincronicidade, efemeridade, enfim características do universo da hipermídia que vão além do signo; e, 
Ver, Ler, Tocar E Participar Do Anúncio Impresso Da Cerveja Sol.

de Fernanda Rodrigues Pucci

ainda, se relaciona com três universos: o real, o virtual e o hipotético e por isso estende sua condição de signo para hipersigno.

Ao verificar modelos artificiais de interação, tem-se a possibilidade de modificação de conteúdos e espaços, uma vez que os signos podem ter diferentes interpretações. Nesse sentido, pode também ser identificada uma relação de proximidade entre o hipersigno multimidiático com os signos utilizados em campanhas publicitárias impressas, apesar de esses últimos terem base em apenas um suporte. A interação caracteriza-se, nesses casos, não apenas pela intervenção de um intérprete, mas também pelo diálogo entre linguagem e suporte. "O hipersigno, sendo objeto dinâmico, virtual e direto das linguagens interativas, é reflexo do signo e o representa. O signo é reflexo e objeto do hipersigno, pois espelha o sentido próprio indutivo dinâmico direcional, ambos se espelham como representantes do mesmo objeto" (Guimarães 2009: em aula).

A peça escolhida para este artigo revela de imediato o componente da interatividade, por se tratar de uma análise semiótica voltada à funcionalidade da propaganda e portanto focada no fato de estar em constante adaptação. Seus elementos não apenas pedem a atenção, mas a exigem, pois sua compreensão depende desta manipulação, ou interação física do receptor, apresentando apelos ao tato e texturas, com ênfase na dinâmica da resposta gestual.

\section{O PROCEDIMENTO DE ANÁLISE DA PEÇA DE LANÇAMENTO DA CERVEJA SOL}

Os conceitos metodológicos que norteiam este artigo permitem decodificar os sentidos das imagens que compõem a peça estudada, facilitando a compreensão dos elementos que a constituem. A abordagem dada à propaganda da cerveja SOL levará em conta as funções de cada um dos registros explorados pela peça em questão: o visual, o verbal e o tátil, bem como seu cruzamento, buscando integrá-los à interpretação.

\subsection{O registro visual}

Como as mensagens publicitárias têm configurações privilegiadas, Martine Joly explica as diversas possibilidades do percurso do olhar, que, segundo ela, orientam a leitura de um anúncio (Joly 1996:98): 
Ver, Ler, Tocar E Participar Do Anúncio Impresso Da Cerveja Sol.

de Fernanda Rodrigues Pucci

- a construção focalizada, quando as linhas de força convergem para um ponto que representa o núcleo da mensagem (um ponto estratégico) e puxam o olhar para aquele ponto;

- a construção axial, quando o eixo do olhar é o centro da mensagem;

- a construção em profundidade, quando a figura principal está à frente e é integrada a uma cena dentro de um cenário em perspectiva;

- a construção sequencial, quando o olhar é conduzido (na maioria das vezes por uma construção em Z) do alto à esquerda, formando um $\mathrm{Z}$ até o final da mensagem, no canto inferior direito.

A autora lembra que existem padrões de leitura visual, os quais conferem valores diferentes às diversas localizações na página (ou tela), em que a direção do olhar seleciona as informações-chave. Além disso, também deve ser lembrada a importância das cores na comunicação visual. Cada cultura efetua a valorização do espectro cromático às necessidades da vida prática que assentam em princípios culturais simbólicos, como mostrou Umberto Eco (1985), ou seja, princípios culturais e raciais que se situam no espaço de percepção entre as categorias semióticas e os processos sensoriais.

Outros elementos relevantes numa mensagem publicitária são a diagramação e a exploração das letras como comunicação visual. Tanto esses elementos quanto as imagens em si estão ligados a certas características que nos permitem abordar criticamente uma imagem publicitária ou analisá-la, como, por exemplo, o grau de iconicidade. Uma imagem é mais icônica que outra na medida em que tem mais propriedades comuns com o próprio objeto, em termos de similaridade. Podemos citar um conjunto de características que permitem uma diferenciação das diversas propriedades de uma imagem:

- qualidades técnicas

- grau de figuração

- grau de iconicidade

- grau de complexidade

- grau de ocupação do campo visual

- espessura da trama e do grão

- presença ou ausência da cor

- dimensão estética e/ou originalidade

Nossa análise procurará levar em conta tais propriedades, lembrando ainda a importância da originalidade que está diretamente ligada à proposta estética de uma 
Ver, Ler, Tocar E Participar Do Anúncio Impresso Da Cerveja Sol.

de Fernanda Rodrigues Pucci

mensagem publicitária. Denise Guimarães (2007) lembra que, embora a publicidade e a arte sejam diferentes, ambas dividem o ideal estético da beleza e da inventividade.

\begin{abstract}
Desse modo, muito embora a criação publicitária submeta-se a diretrizes (do cliente, da agência, do público-alvo, entre outros), um cartaz, um banner ou um anúncio esteticamente mal resolvido, por exemplo, não atinge plenamente seus objetivos comunicacionais e persuasivos. (Guimarães 2007:157)
\end{abstract}

Na peça em análise, é preciso salientar o papel da sinestesia, pois, em se tratando de propaganda de cerveja, é indispensável que as impressões ligadas ao tato (algo gelado) e ao sabor apareçam nas imagens em questão. São estratégias de certa forma bastante comuns, ligadas ao imaginário ocidental. Da mesma forma, o clima do verão, época ideal para o consumo da bebida, é enfatizado pelo uso das cores e pela imagem do calor do SOL, que foi escolhido como nome do produto.

\title{
4.2 O registro verbal
}

A partir do nome do produto, observamos sua sonoridade e a exploração visual da imagem formada pelas letras, ou seja, seus elementos icônicos. Deve ser enfatizada também a diagramação das páginas que compõem o anúncio, em que se verificam uma distribuição dos caracteres tipográficos muito adequada, informações precisas e predominantemente denotativas sobre o produto.

As mensagens, de uma maneira geral, procuram fugir à redundância entre as informações icônicas e os significados dos signos verbais, porém temos que admitir que, no caso do anúncio em questão, a redundância observada é uma estratégia necessária para que o efeito desejado seja conseguido.

\subsection{O registro tátil}

A interatividade da peça estudada depende basicamente do tato e por meio dele leva à manipulação das páginas em sua materialidade.

Observa-se que a peça exige a alteração do seu estado de inércia para poder produzir vários sentidos, que vão muito além de uma leitura passiva de uma propaganda impressa. O que se apresenta então é a natureza complexa da linguagem interativa que 
Ver, Ler, Tocar E Participar Do Anúncio Impresso Da Cerveja Sol.

de Fernanda Rodrigues Pucci

aproxima a natureza dos fenômenos da hipermídia, em função do volume de informações a serem assimiladas e também dos percursos (links) possíveis de serem seguidos.

\section{A INTERPRETAÇÃO, E A INTEGRAÇÃO DOS REGISTROS}

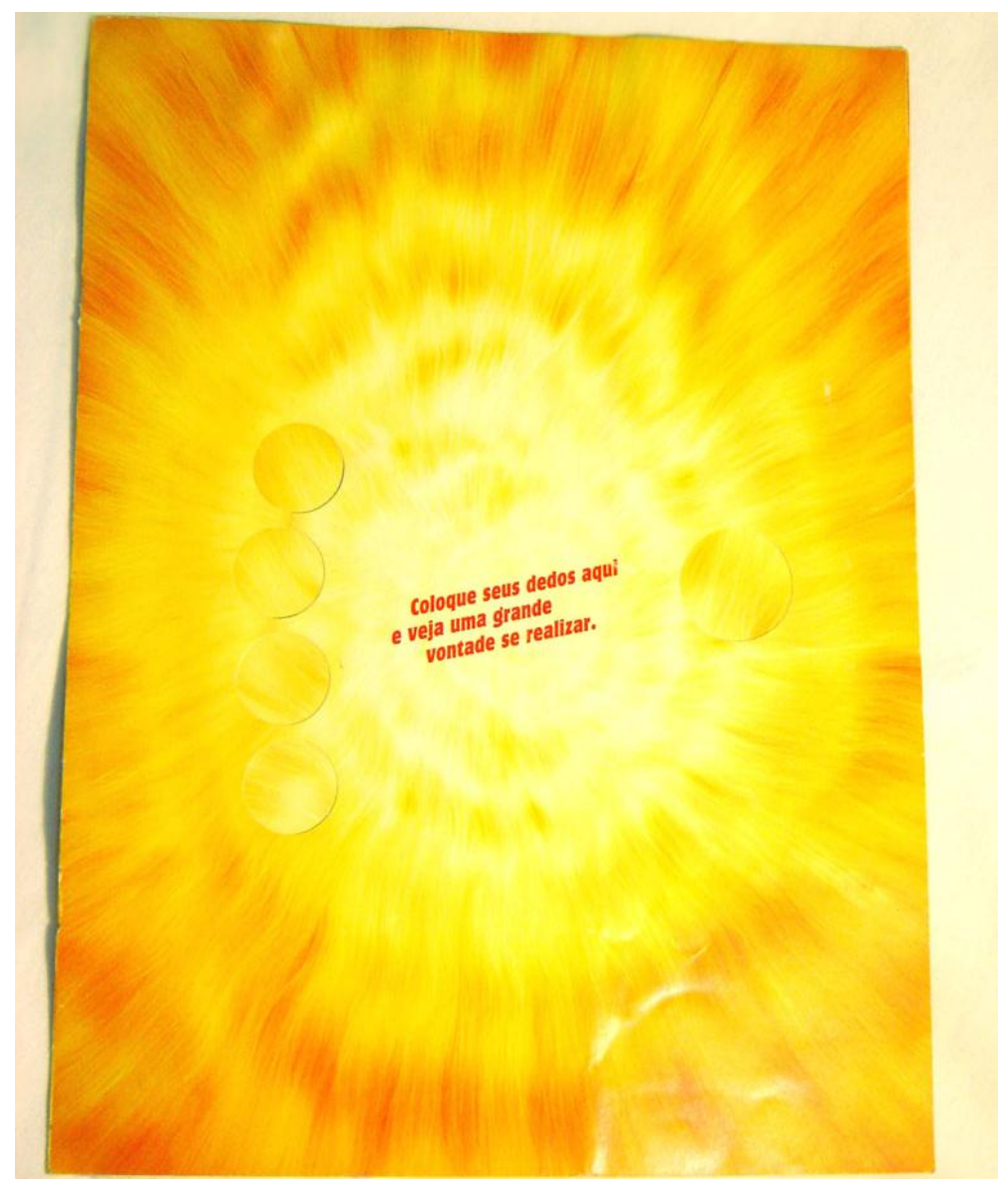

Fig. 1 - Imagem Inicial

(Fotos de Fernanda R. Pucci)

A imagem da figura 1 e as que se seguem são de uma das peças da campanha publicitária de lançamento da cerveja SOL no Brasil, desenvolvida pela agência Fisher América. Trata-se de um encarte de revistas com papel diferenciado, mais grosso e mais pesado que as páginas das revistas. Ao passar as folhas da revista o primeiro contato é visual. A página salta aos olhos por suas cores fortes de amarelo em diferentes tons, também pelo laranja e pelo vermelho da mensagem escrita. A imagem passa uma ideia de fogo, de calor, e com um pouco mais de atenção nos remete ao SOL.

Em seguida o que nos chama a atenção são os buracos que a página possui e com o toque das mãos já se sente a diferença de papel. Facilmente entende-se que os buraquinhos 
Ver, Ler, Tocar E Participar Do Anúncio Impresso Da Cerveja Sol.

de Fernanda Rodrigues Pucci

estão ali para colocarmos nossa mão, ideia que se reforça ao lermos o texto "Coloque seus dedos aqui e veja uma grande vontade se realizar."

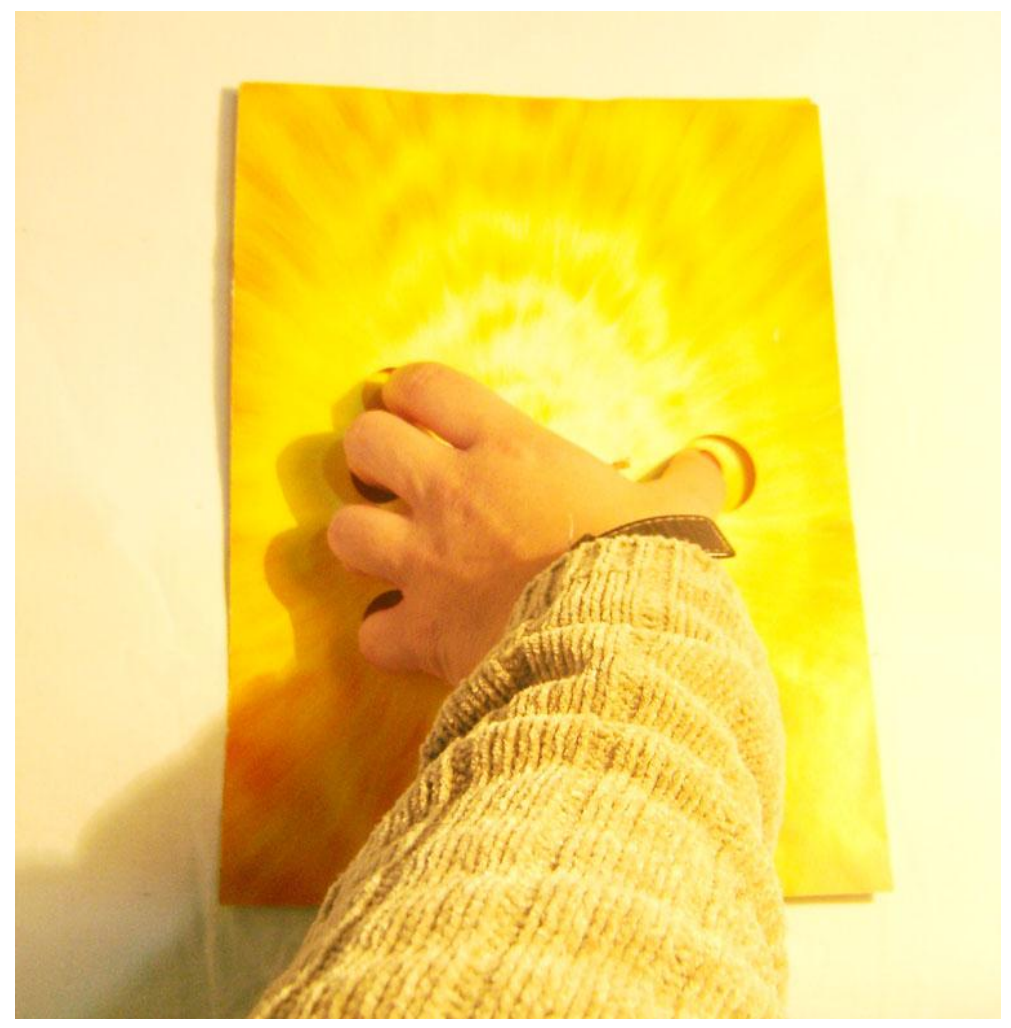

Fig. 2 - O gesto induzido (foto da interação com a mensagem)

Muitas pessoas, por curiosidade, colocam os dedos ali para ver a mensagem se completar e descobrir, conforme sugere o texto, qual é o desejo. Por outro lado há pessoas que preferem ver logo a página seguinte mesmo sem colocar a mão no local indicado.

Depois de tomarmos a atitude proposta e virarmos a página, o que acontece naturalmente ao colocar os dedos nos buracos, vemos que estamos segurando naquela mão uma garrafa de cerveja SOL. Mesmo aquelas pessoas que passaram a página sem colocar a mão no lugar proposto acabam voltando e colocando para ver a mensagem e ter a impressão de estar segurando a garrafa. 


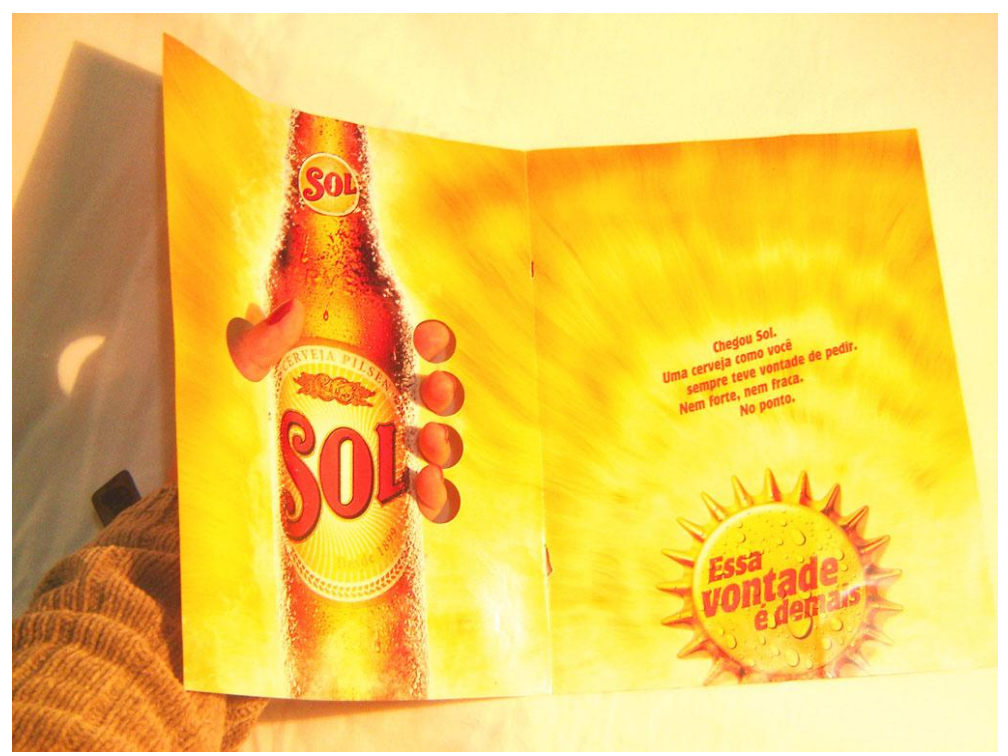

Fig. 1 - Imagem que ocupa 2 páginas

A imagem da garrafa posicionada ao centro da primeira metade da página é bastante fiel, inclusive nas cores, a uma garrafa de cerveja, porém nota-se que o fundo continua amarelo, cor de fogo, tom que ilumina a garrafa, dando uma sensação de calor, de verão. Essa ideia de calor é transmitida também pelo suor da garrafa e pelo vapor que ela expele como se o calor do ambiente estivesse criando um choque de temperaturas, derretendo a água de fora da garrafa. Podemos notar facilmente as gotinhas escorrendo. Tais gotas e outros elementos similares são os chamados iconogramas ou signos iconográficos (segundo Umberto Eco). A representação iconográfica pode ser reconhecida mundialmente, fazendo parte de um repertório de imagens já conhecidas o que reforça o sentido de determinadas mensagens visuais.

No rótulo, visualizamos a logomarca SOL em vermelho, devidamente destacada com contornos em preto e dourado, acima os símbolos de dinheiro e valor, ligados à ideia de qualidade do produto, e um pouco mais acima o escrito indicativo de que a cerveja é do tipo pilsen, a qual naturalmente possui uma coloração dourada.

Abaixo da logomarca está escrito apenas “Desde 1899”, o que demonstra certa tradição na fabricação de cerveja, apesar de ser um lançamento no Brasil.

A garrafa não aparece nesta página por inteiro, seu fundo foi cortado e a boca também, mas na página ao lado vemos a tampinha com gotas, como se também estivesse molhada de suor. Seu formato é de SOL, como os de desenhos infantis, o que deixa claro a intenção de relacionar com o nome da bebida e com o verão. Com isso percebemos que a mensagem ocupa a página dupla e a página direita complementa a esquerda. A tampinha 
Ver, Ler, Tocar E Participar Do Anúncio Impresso Da Cerveja Sol.

de Fernanda Rodrigues Pucci

não está centralizada, e sim ao rodapé da página, o que faz referência a um por do SOL, momento bastante oportuno para se consumir o produto no verão. Nela está escrito "Essa vontade é demais" em uma fonte bastante grande e sóbria, padrão até, por isso chama mais a atenção do que o texto que completa a mensagem. O texto está logo acima da imagem da tampinha, no mesmo padrão da indicação da primeira página. Está posicionado com certa inclinação para a esquerda como se acompanhasse os raios do SOL. Nele tem os dizeres "Chegou SOL. Uma cerveja como você sempre teve vontade de pedir. Nem forte, nem fraca. No ponto.” A mensagem escrita não complementa as intenções da imagem, mas passa as informações básicas sobre características da nova cerveja.

Este tipo de imagem, que evoca um significado convencionalmente estabelecido, enquadra-se no que Umberto Eco classifica como artifícios próprios para suscitarem emoções, por se tratarem de situações retóricas que não estão tradicionalmente catalogadas entre os argumentos retóricos verbais. São bastante utilizados pela publicidade em conjunto com os códigos verbais.

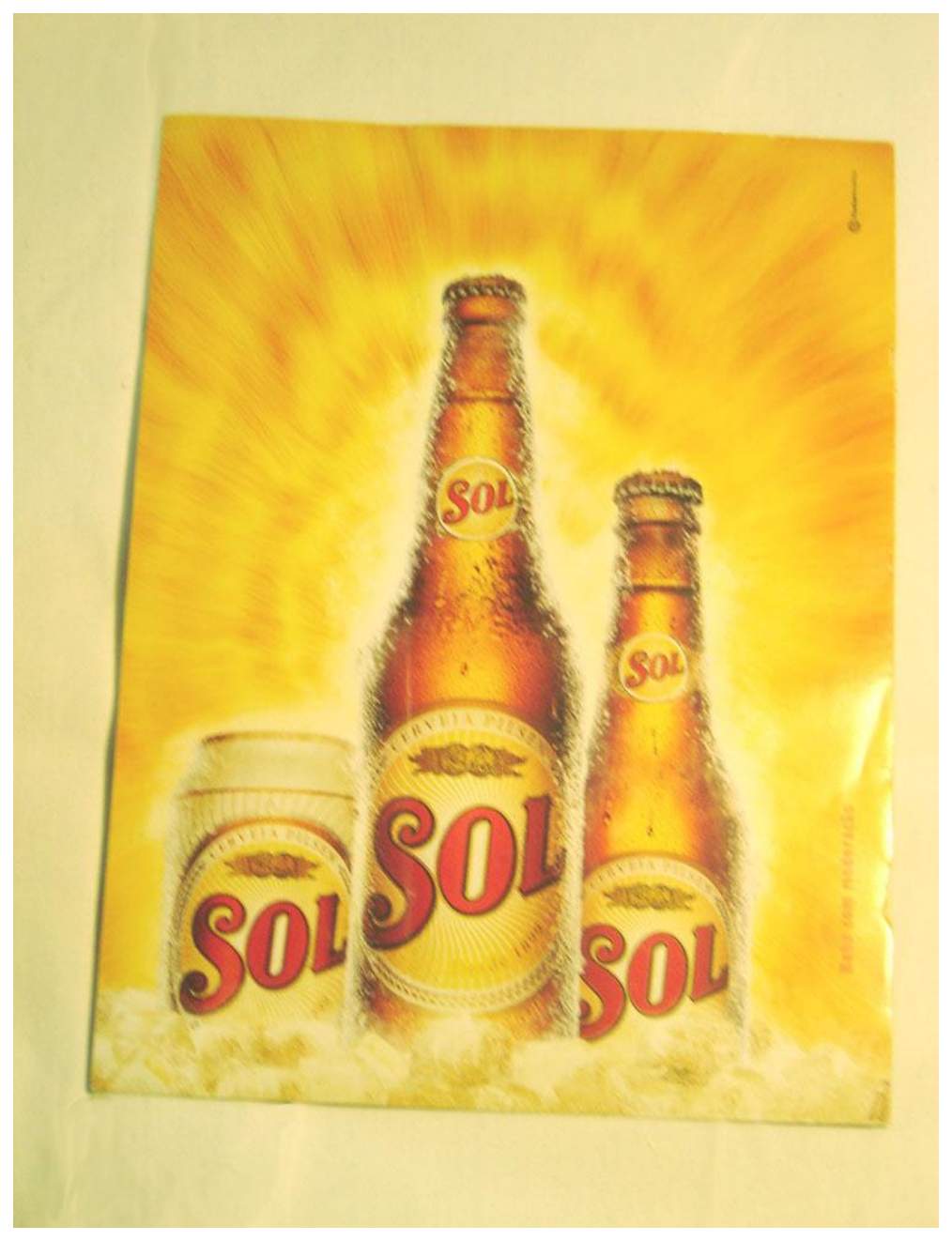


Ver, Ler, Tocar E Participar Do Anúncio Impresso Da Cerveja Sol.

de Fernanda Rodrigues Pucci

Fig. 4 - As três embalagens

$\mathrm{O}$ fato de serem três imagens do mesmo produto, em diferentes embalagens que conservam a identidade visual, pode também remeter à simbologia do número três, com suas associações á ideia da perfeição, cujo exemplo marcante é a Santíssia Trindade. Além disso, as opções cromáticas remetem às simbologias do fogo, quando ligadas à fatores positivos de criação e vida.

Para concluir a mensagem viramos a página e ainda no mesmo fundo vemos as variedades de embalagem da bebida. Agora a garrafa mais comum da cerveja aparece ao centro e por inteira, não conseguimos ver seu fundo por ela estar com a base imersa em gelo, ainda vemos ao lado esquerdo a embalagem de latinha e a versão long neck à direita, ambas também no gelo. Nesta página a bebida é o centro, inclusive a iluminação em torno dela é bastante evidente com branco. O centro do SOL que compõe o fundo está atrás da imagem das embalagens fazendo com que se evidenciem ainda mais em primeiro plano.

No canto inferior direito da página foi colocada a advertência obrigatória por lei para bebidas alcoólicas, dizendo "Beba com moderação" em letras vermelhas de acordo com o padrão de alerta.

\section{CONCLUSÃO}

Retomando a força da interação e o fato desta exigir uma manipulação, com apelos ao tato e às texturas, e a ênfase na dinâmica da resposta gestual do leitor, podemos concluir que a mensagem publicitária analisada é bem construída. Percebe-se o uso eficiente de uma retórica persuasiva, tanto no nível visual quanto no verbal. Devemos, contudo, assinalar o uso repetido da imagem do produto, como uma redundância estratégica, porém muito próxima aos estereótipos. O que realmente torna a mensagem original é o apelo ao manuseio, que é bastante eficaz ao conduzir o leitor a interagir com a peça publicitária aqui analisada.

O sucesso de qualquer marca depende de como ela se comunica com o seu público. É preciso saber primeiro como o consumidor pensa, fala, sente e age, para despertar sua atenção e penetrar em sua mente, tornando-se algo memorável e talvez até uma espécie de mito. A propaganda analisada demonstra a consciência de que uma mensagem original e adequadamente construída, quando eficazmente veiculada, pode assegurar o melhor 
Ver, Ler, Tocar E Participar Do Anúncio Impresso Da Cerveja Sol.

de Fernanda Rodrigues Pucci

desempenho e rentabilidade do produto no mercado. Os componentes da cadeia de valor da marca da cerveja SOL revelam, portanto, eficácia comunicativa e persuasiva.

\section{REFERÊNCIAS BIBLIOGRÁFICAS}

BARTHES, R. Elementos de semiologia. São Paulo: Cultrix, 1985.

CITELLI, A. Linguagem e persuasão. São Paulo: Ática, 1985.

ECO, H. Estrutura ausente: introdução à pesquisa semiológica. São Paulo: Perspectiva, 1997.

. Tratado Geral de Semiótica. São Paulo: Perspectiva, 1976.

Os limites da interpretação. São Paulo: Perspectiva, 2000.

EPSTEIN, Isaac. O signo. 2.ed. São Paulo: Ática, 1986.

GUIMARÃES, D.A.D. Comunicação tecnoestética nas mídias audiovisuais. Porto Alegre: Sulina, 2007.

JOLY, M. Introdução à análise da imagem. Campinas: Papirus, 1996.

PEIRCE, C.S. Semiótica e filosofia. São Paulo: Cultrix, 1975.

SANDMANN, A. J. A linguagem da propaganda. 2. ed. São Paulo: Contexto, 1997.

SANTAELLA, L. A assinatura das coisas. Rio de janeiro: Imago, 1992

Teoria Geral dos signos. Como as linguagens significam as coisas. São Paulo: Pioneira, 2000.

Semiótica Aplicada. São Paulo: Pioneira Thomson Learning, 2002.

TEIXEIRA PRIMO, A.F.; MOURA, L., SILVEIRA, G.; SANTOS, L.A. "Televisão interativa: um meio de comunicação democrático?” Disponível em: http://usr.psico.ufrgs.br/ aprimo/pb/tv.htm . Acesso em: 12/02/2008.

Artigo recebido: 30/06/2011

Artigo aprovado: 10/06/2011 